\title{
ANALISIS PENILAIAN PERUSAHAAN PT. PERUSAHAAN GAS NEGARA TBK
}

\author{
Clarisa Felicia \\ Universitas Sumatera Utara \\ clarisafelicia2020@gmail.com
}

\begin{abstract}
Abstrak
Salah satu sektor penting bagi perkembangan ekonomi Indonesia adalah sektor minyak dan gas bumi . Sayangnya diketahui adanya penurunan dari sektor minyak dan gas bumi dimana pendapatan negara dari sektor ini turun hingga $80 \%$ dari $\mathrm{Rp}$. 216.000.000.000.000 (Rp. 216 Triliun) di tahun 2014 menjadi Rp. 44.000.000.000.000 (Rp. 44 Triliun) pada tahun 2016. PT. Perusahaan Gas Negara TBK adalah BUMN yang terbesar di bidang transportasi dan distribusi gas bumi. Penelitian ini bertujuan untuk mengetahui nilai intrinsik per saham PT. Perusahaan Gas Negara TBK dengan metode discounted cash flow menggunakan free cash flow ke perusahaan. Data diperoleh dari laporan keuangan PT. Perusahaan Gas Negara TBK pada tahun 2013 hingga tahun 2018. Hasil penelitian menunjukkan bahwa nilai intrinsik per saham dari PT. Perusahaan Gas Negara TBK adalah Rp. 6.757,72.
\end{abstract}

Kata Kunci: Corporate Valuation; Penilaian Perusahaan

\section{PENDAHULUAN}

Gas alam merupakan komponen penting dari pasokan energi dunia dan salah satu sumber energi paling berguna dari semua sumber energi yang merupakan bahan bakar fosil yang muncul dari sisa-sisa tumbuhan, hewan, dan mikroorganisme yang tersimpan jauh di bawah tanah selama jutaan tahun. Gas Indonesia diproduksi untuk diekspor untuk menambah pendapatan negara dan digunakan untuk kepentingan dalam negeri juga. (Investments, 2019).

Indonesia menghabiskan puluhan tahun mengandalkan kontribusi sektor minyak dan gas bumi terhadap pertumbuhan ekonomi. Namun sayangnya diketahui adanya penurunan dari sektor minyak dan gas bumi dimana pendapatan negara dari sektor ini turun hingga 80\% dari Rp. 216.000.000.000.000 (Rp. 216 Triliun) atau (14\% dari penerimaan negara) di tahun 2014 menjadi Rp. 44.000.000.000.000 (Rp. 44 Triliun) atau (2,8\% dari penerimaan negara), pada tahun 2016. Siaran pers Kementerian Energi dan Sumber Daya Mineral (Kementerian ESDM) 
menunjukkan penerimaan negara yang tidak diaudit sebesar Rp138.000.000.000.000 triliun (Rp. 138 Triliun) dari sektor migas pada tahun 2017, yang merupakan 117\% dari target (Pwc.com, 2019 ). PT. Perusahaan Gas Negara TBK adalah BUMN yang terbesar di bidang transportasi dan distribusi gas bumi. Tujuan perusahaan adalah menyediakan keahlian, energi, dan infrastruktur yang dibutuhkan untuk meningkatkan pertumbuhan ekonomi Indonesia dalam jangka panjang. (Investments, 2019).

Untuk mengembangkan bisnis, PT. Perusahaan Gas Negara TBK akan melakukan akuisisi terhadap PT Pertamina Gas. Akuisisi tersebut merupakan bagian dari pembentukan holding company di bidang energi oleh Badan Usaha Milik Negara. kedua belah pihak memutuskan hanya mengakuisisi satu unit PT Pertamina Gas, yaitu PT Pertagas Niaga. Disusul dengan mengakuisisi 4 unit PT Pertamina Gas lainnya yaitu PT Perta Arun Gas, PT Perta-Gas, PT Perta Samtan Gas, dan PT Perta Kalimantan Gas (Post, 2019).

Untuk metode pembayaran atas pengambil alihan ada dua, yakni. 50\% dari total harga beli atau setara Rp10,09 triliun akan menggunakan metode pembayaran tunai. Lalu, perusahaan akan menerbitkan Surat Sanggup untuk sisa saham. Ini menyiratkan bahwa PT. Perusahaan Gas Negara TBK perlu mengambil utang senilai lebih dari Rp 11,0 triliun (sekitar USD \$ 769 juta) (Investments, 2018). Proses akuisisi juga mempengaruhi saham PT. Perusahaan Gas Negara TBK, saham PT. Perusahaan Gas Negara TBK masih bergerak di zona merah perdagangan saham pada Rabu (7/4/2018). Harga saham PT. Perusahaan Gas Negara TBK di zona merah terjadi setelah perusahaan mengumumkan akan mengakuisisi.

Pelemahan harga saham PT Perusahaan Gas Negara Tbk terjadi setelah PT Perusahaan Gas Negara Tbk dan Pertamina melakukan transaksi material dengan membeli $51 \%$ saham PT Pertamina Gas yang merupakan anak perusahaan Pertamina.

\section{LANDASAN TEORI}

\section{Merger}

Dalam merger, dua atau lebih perusahaan yang menjalankan bisnis serupa bergabung menjadi satu dan membangun perusahaan baru. Hal ini bertujuan untuk mengurangi jumlah pesaing. Penggabungan juga termasuk keputusan bersama antara dua perusahaan untuk berkumpul dan menjadi satu objek. Semakin sedikit perusahaan yang berharga menderita identitas dan menjadi elemen dari perusahaan nilai lebih lanjut, yang memegang keberadaan aslinya (Devi, 2016). Ada empat jenis merger yaitu merger horizontal, vertikal, konglomerat, dan kongenerik.

\section{Acquisition}

Akuisisi terjadi ketika satu perusahaan membeli sebagian besar atau sebagian besar saham perusahaan lain untuk mengambil kendali. Ini terjadi ketika perusahaan pembelian mendapatkan lebih dari setengah kepemilikan di perusahaan tujuan (Piesse et al., 2013). Ada beberapa jenis akuisisi, seperti akuisisi yang dinegosiasikan, akuisisi pasar terbuka, dan akuisisi bail out. 


\section{Valuation}

Setiap perusahaan memiliki tiga bagian yang harus diperhatikan dalam penilaian yang efisien. Dua diantaranya diidentifikasikan dengan sumber daya perusahaan dan earning power perusahaan yang tampak pada laba dan arus kas. Untuk memulainya, sumber daya perusahaan dapat dinilai dengan insentif penjualan bersih ke nilai ekonomi yang ditandai dengan estimasi arus kas yang didiskontokan selama umur ekonomis dari sumber daya tertentu. Kedua, kekuatan laba perusahaan, dapat dinilai baik dengan pendekatan arus kas diskonto dan rasio $\mathrm{P} / \mathrm{E}$ dan indikator lain yang dapat digunakan dalam kapitalisasi. Ketiga, oleh karena itu dari keunikan organisasi, yang dapat diperlakukan sebagai rabat potensial yang lebih rendah atau lebih penting daripada perkiraan yang ditetapkan sumber daya organisasi dan kekuatan pemenang (Orsag dan Mcclure, 2013).

\section{Discounted Cash Flow}

Dalam pendekatan ini, nilai aset apa pun adalah nilai sekarang dari arus kas masa depan yang diharapkan darinya. Arus kas akan berbeda dari satu aset ke aset lain seperti dividen untuk saham, kupon (premium) dan nilai nominal untuk obligasi dan arus kas setelah pajak. Tingkat diskonto akan menjadi target bahaya yang diperkirakan, dengan tarif yang lebih tinggi untuk sumber daya yang semakin berbahaya dan menurunkan tarif untuk sumber daya yang kurang berbahaya (Gitman, 2012).

\section{Free Cash Flow}

Nilai arus kas yang dapat digunakan oleh investor setelah perusahaan memenuhi seluruh biaya operasional dan investasi yang telah dibayarkan dalam aktiva tetap bersih dan aktiva lancar bersih. Ini adalah pengukuran penting karena dapat menunjukkan seberapa efektif perusahaan dalam menghasilkan uang (Gitman, 2012).

\section{Free Cash Flow to Firm}

Arus kas bebas ke perusahaan adalah total arus kas ke semua pemegang klaim di perusahaan, termasuk pemegang saham, pemegang obligasi dan pemegang saham preferen. Karena arus kas ini sebelum pembayaran utang, sering disebut sebagai arus kas yang tidak dipengaruhi. Arus kas bebas ke perusahaan ini tidak memasukkan manfaat pajak apa pun karena pembayaran bunga. Karena penggunaan biaya utang setelah pajak dalam biaya modal sudah mempertimbangkan manfaat ini dan memasukkannya ke dalam arus kas akan menghitungnya dua kali lipat (Damodaran, 2005).

\section{Weighted Average Cost of Capital}

Menunjukkan biaya modal masa depan yang diharapkan seiring berjalannya waktu dengan menimbang jenis biaya modal dengan persentasenya dalam struktur modal perusahaan. Dimana biaya ekuitas dapat dihitung dengan menambahkan tingkat bebas risiko dengan jumlah perkalian antara premi risiko pasar dengan beta perusahaan. Dan cost of debt dapat dihitung dengan menggunakan prime lending rate dari bank yang meminjamkan uang kepada perusahaan (Gitman, 2012). 


\section{Terminal Value}

Mengacu pada nilai prediksi bisnis yang berada di atas periode perkiraan. Ini adalah bagian penting dari model keuangan yang menunjukkan persentase besar dari total nilai perusahaan. Pendekatan yang dapat digunakan untuk nilai terminal adalah pertumbuhan abadi. Metode pertumbuhan perpetual mengasumsikan bahwa perusahaan akan terus menghasilkan arus kas bebas pada keadaan ternormalisasi selamanya (perpetuity) (Gitman, 2012).

\section{METODE PENELITIAN}

Penelitian ini akan dimulai dengan mengidentifikasi masalah, setelah masalah diidentifikasi, langkah selanjutnya adalah membuat pertanyaan penelitian dan tujuan penelitian yang sesuai dengan ruang lingkup dan batasan yang telah disebutkan sebelumnya. Kemudian, mengkaji literatur yang bertujuan untuk mendukung teori yang disebutkan dalam penelitian ini dan juga mengumpulkan semua penelitian sebelumnya yang terkait untuk mendukung penelitian ini. Setelah itu, pengumpulan data menggunakan data sekunder dari website perusahaan, buku, jurnal, dan artikel. Pengumpulan data dilakukan dengan metode kuantitatif. Kemudian dilakukan analisis data dengan menggunakan valuasi. Langkah terakhir adalah membuat kesimpulan dan rekomendasi dari hasil penelitian.

\section{HASIL DAN PEMBAHASAN}

\section{Discounted Cash Flow (Income Statement Assumption)}

Asumsi yang dibuat dalam proyeksi laporan laba rugi didasarkan pada data historis perusahaan, kondisi industri, dan berita yang tersedia di pasar.

\section{Discounted Cash Flow (Free Cash Flow to the Firm)}

Sebagaimana tercantum pada laporan laba rugi pro forma dan neraca pro forma, tabel 4.3 memberikan perhitungan Arus Kas Bebas Perusahaan Gas Negara untuk lima tahun ke depan, yaitu dari tahun 2019 sampai dengan tahun 2024. Tarif pajak yang digunakan adalah $25 \%$ karena itu adalah tarif normal untuk pajak penghasilan badan.

\section{Discounted Cash Flow (Weighted Average Cost of Capital)}

Suku bunga bebas risiko, informasi akan dikumpulkan dari suku bunga SBI (Sertifikat Bank Indonesia) yaitu 7,36\%. Nilai premi risiko pasar adalah 8,6\% berdasarkan rata-rata premi risiko ekuitas di Indonesia. Beta yang digunakan adalah 1,66 , berdasarkan Reuters. Untuk cost of debt, nilai diperoleh dengan mendapatkan rata-rata prime lending rate dari bank yang meminjamkan uang kepada perusahaan, yaitu $7,61 \%$. Karena perusahaan menggunakan utang untuk pembiayaan, maka perhitungan rata-rata tertimbang biaya modal PGAS adalah $12,13 \%$.

\section{Discounted Cash Flow (Terminal Value)}

Dalam menghitung nilai terminal, asumsi yang akan digunakan adalah pertumbuhan PGAS setelah tahun 2023 akan stabil, karena harga gas bumi akan tetap konstan dan stabil. Laju pertumbuhan terminal akan menggunakan laju ratarata produk domestik bruto di Indonesia sebesar 5,28\% dan the terminal value menjadi 15,612,268,403.53. 


\section{Discounted Cash Flow (Value of the Firm)}

Untuk mencari nilai perusahaan, dapat dihitung dari mendiskontokan arus kas bebas dan nilai terminal dengan menggunakan biaya modal rata-rata tertimbang. Karena laporan keuangan perusahaan disajikan dalam mata uang USD, maka dalam menghitung nilai perusahaan, kurs yang digunakan mengacu pada kurs perusahaan yang tercantum dalam laporan keuangan yaitu $1 \mathrm{USD}=\mathrm{Rp} 14.238$. Pada tahun ke 5 atau 2023, nilai perusahaan menjadi USD11.505.649.021 atau setara dengan Rp163.817.430.760.790,00 Nilai intrinsik per saham menjadi Rp6.757,72 dengan harga penutupan per saham 31 Desember 2018 sebesar Rp2.120,00.

\section{KESIMPULAN}

Untuk mengetahui nilai perusahaan digunakan metode discounted cash flow. Berdasarkan perhitungan pada bab 4, nilai intrinsik per saham Perusahaan Gas Negara berada pada Rp6.757,72 atau lebih tinggi dari harga penutupan pada 31 Desember 2018 yang sebesar Rp2.120 per saham..

Berdasarkan perhitungan tersebut, penulis merekomendasikan untuk membeli saham di Perusahaan Gas Negara. Karena nilai intrinsik per saham Rp6.757,72 lebih tinggi dari harga per saham Rp2.120, maka menunjukkan kenaikan sebesar $218,76 \%$.

\section{REFERENSI}

Damodaran, A. (2005) The Value of Synergy, SSRN. doi: 10.2139/ssrn.841486.

Gitman, L. J. and C. J. Z. (2012) 'Principles of Managerial Finance 13th Edition', in Prentice Hall. doi: 10.1016/0890-8389(89)90087-5.

Piesse, J. et al. (2013) 'Merger and Acquisition: Definitions, Motives, and Market Responses', in Encyclopedia of Finance. doi: 10.1007/978-1-4614-53604 28.

Devi, N., 2016. Merger and Acquisition. International Journal for Research in Business, Management and Accounting, 2(2), p. 8

Orsag, S. and Mcclure, K. G. (2013) 'Modified net present value as a useful tool for synergy valuation in business combinations', Journal of Economics. doi: 10.1186/gb-2009-10-12-r14.

Investments, I. (2019). Natural Gas in Indonesia - Indonesian LPG Production \& Export | Indonesia Investments. [online] Indonesia-investments.com. Availableat:https://www.indonesiainvestments.com/business/commodities/ natural-gas/item 184? [Accessed 3 Feb. 2019]..

Investments, I. (2019). Perusahaan Gas Negara - PGN | Indonesia Investments. [online]Indonesia-investments.com.Availableat: https://www.indonesiainvestments.com/business/indonesian companies/perusahaan-gas-negara/item199? [Accessed 3 Feb. 2019]. 